\title{
The impact of management practices to prevent and control mycotoxins in the European food supply chain: MyToolBox project results
}

\author{
M. Focker ${ }^{1 *}$, H.J. van der Fels-Klerx ${ }^{1,2}$, N. Magan ${ }^{3}$, S.G. Edwards ${ }^{4}$, M. Grahovac ${ }^{5}$, F. Bagi ${ }^{5}$, D. Budakov ${ }^{5}$, M. Suman ${ }^{6}$, \\ G. Schatzmayr ${ }^{7}$, R. Krska ${ }^{8,9}$ and M. de Nijs ${ }^{2}$ \\ ${ }^{1}$ Business Economics Group, Wageningen University E Research, Hollandseweg 1, 6706 KN Wageningen, the Netherlands; \\ ${ }^{2}$ Wageningen Food Safety Research (WFSR), Wageningen University E Research, Akkermaalsbos 2, 6708 WB Wageningen, \\ the Netherlands; ${ }^{3}$ Applied Mycology Group, Environment and AgriFood Theme, Cranfield University, Cranfield MK43 OAL, \\ United Kingdom; ${ }^{4}$ Harper Adams University, Newport, Shropshire TF10 8NB, United Kingdom; ${ }^{5}$ University of Novi Sad, \\ Faculty of Agriculture, Trg Dositeja Obradovica 8, 21000 Novi Sad, Serbia; ${ }^{6}$ Advanced Research Laboratory, Barilla G.R. \\ F.lli SpA, via Mantova 166, 43122 Parma, Italy; ${ }^{7}$ BIOMIN Research Center, Technopark 1, 3430 Tulln, Austria; ${ }^{8}$ Institute \\ of Bioanalytics and Agro-Metabolomics, Department IFA-Tulln, University of Natural Resources and Life Sciences, Vienna \\ (BOKU), 3430 Tulln, Austria; ${ }^{9}$ Institute for Global Food Security, School of Biological Sciences, Queens University Belfast, \\ University Road, Belfast BT7 1NN, United Kingdom; marlous.focker@wur.nl
}

Received: 6 May 2020 / Accepted: 28 October 2020

(c) 2021 Wageningen Academic Publishers

\section{OPEN ACCESS @(1)@()}

RESEARCH ARTICLE

\begin{abstract}
The presence of mycotoxins in cereals has led to large economic losses in Europe. In the course of the European project MyToolBox, prevention and control measures to reduce mycotoxin contamination in cereals were developed. This study aimed to estimate the impact of these prevention and control measures on both the reduction in crop losses and the increased volume of crops suitable for food and/or feed. It focused on the following measures: the use of fungicides during wheat cultivation, the use of resistant maize cultivars and/or biocontrol during maize cultivation, the use of real time sensors in storage silos, the use of innovative milling strategies during the pasta making process, and the employment of degrading enzymes during the process of bioethanol and Dried Distillers Grains with Solubles (DDGS) production. The impact assessment was based on the annual volume of cereals produced, the annual levels of mycotoxin contamination, and experimental data on the prevention and control measures collected in the course of the MyToolBox project. Results are expressed in terms of reduced volumes of cereals lost, or as additional volumes of cereals available for food meeting the current European legal limits. Results showed that a reduction in crop losses as well as an increase in the volume of crops suitable as food and/or feed is feasible with each proposed prevention or control measure along the supply chain. The impact was the largest in areas and in years with the highest mycotoxin contamination levels but would have less impact in years with low mycotoxin levels. In further research, the impact assessment may be validated using future data from more years and European sites. Decision makers in the food and feed supply chain can use this impact assessment to decide on the relevant prevention and control strategies to apply.
\end{abstract}

Keywords: impact assessment, MyToolBox, mycotoxin mitigation, food safety, food security

\section{Introduction}

Mycotoxins, toxic secondary metabolites produced by fungi, are regarded as most important natural toxins that may affect the health of humans and animals. Besides these health issues, mycotoxin contamination of plant crops for food and feed production, can compromise food security and international trade. The European Commission (EC) estimates that mycotoxin contamination results in annual global crop losses of 5 to $10 \%$ (EC, 2015). Hence, $€ 1.2-2.4$ billions of lost income for cereals can be estimated in the European Union (EU) based on the annual production of 
133 million tonnes (MT) of wheat, $68 \mathrm{MT}$ of maize and $8 \mathrm{MT}$ of oats (Eurostat, 2015, 2019). Alleviating these losses by only $1 \%$ could provide significant savings of approximately $€ 12-24$ million in the EU, and could increase consumer confidence in safe food and EU competitiveness.

Prevention and control of mycotoxin contamination is, however, highly complex due to regional and seasonal related variations in mycotoxigenic fungal diversity and their associated mycotoxin occurrence. This will also be influenced by local climatic conditions and the applied crop management strategies. Preventing the incidence and level of contamination of food and feed commodities with these toxic secondary metabolites therefore continues to be a challenge to those agricultural and food industries that are vulnerable to contamination. This is particularly important in the context of the global developments related to climate change, which have shown to affect mycotoxin contamination of cereals in Europe (Battilani et al., 2016) and also worldwide (Tirado et al., 2010).

The EU has strict (official) controls in place for imports of food and feed ingredients and finished products, and enforcement in the EU shows that mycotoxins are number one on of the list of the RASFF notifications for contaminants (RASFF, 2019). Despite this strict enforcement, aflatoxin $M_{1}$, originating from contaminated feed, was detected in milk in the EU in 2013 (Miocinovic et al., 2017). Some population groups were exposed to mycotoxins levels that have impacted on human and animal health (Heyndrickx et al., 2015; Kang'ethe et al., 2017; Van der Fels-Klerx et al., 2019). Stakeholders can minimise and reduce mycotoxin contamination of crops, and the subsequent processed food and feed products, by relying on practical and affordable tools that have been developed over the last two decades. These tools have led to some reductions in crop losses along the food and feed chain. The improvements in traceability systems and communication technologies has also provided benefits to consumers. The uptake of existing and novel findings is essential for the practical implementation of this knowledge that should be used along the whole food and feed supply chain.

Some of the new challenges were addressed by MyToolBox (www.mytoolbox.eu), a four year project (2016-2020), funded by the EC, with 23 partners from 11 countries, with $40 \%$ of the project partners form industry. The main goal of MyToolBox was the development and merging of various management practices along the entire food production chain to significantly reduce mycotoxin contamination and product losses. These practices were integrated into an e-tool to assist decision making for all actors in the food and feed supply chain (H.J. Van der Fels-Klerx, personal communication). A combination of pre- and post-harvest management practices was initiated by MyToolBox to reduce mycotoxin contamination and the loss of crops caused by mycotoxins (Krska et al., 2016). One of the overarching objectives of the MyToolBox project was to reduce the mycotoxin contamination of food and feed and to reduce waste. This reduction can be expressed using impact assessment studies. Published impact assessment studies mainly focus on macro defined situations and seldomly on an individual strategy (Ndenn et al., 2015; Udomkun et al., 2017). With such studies, the uptake of the strategy by the actors in the supply chain is not considered.

The aims of this study were to (1) quantify the impact of various improved prevention and control strategies for mycotoxins in cereals, as developed in the MyToolBox project, on mycotoxin contamination and losses in the test areas, and (2) assess the impact at various levels of uptake by the actors, in the test area as well as extrapolated throughout Europe.

\section{Case studies and methods}

\section{Case study description}

Five case studies were identified, based on prevention and control strategies in various stages of the food supply chain investigated in the MyToolBox project. Each case is briefly described below.

\section{Case 1. Pre-harvest - use of a fungicide to control Fusarium head blight}

The proposed pre-harvest strategy to control Fusarium head blight (FHB) and related deoxynivalenol (DON) contamination of wheat in the UK was the use of a newly developed fungicide Adepidyn ${ }^{\mathrm{TM}}$ (developed by Syngenta, Basel, Switzerland). Wheat is the most widely grown arable food and feed crop in the UK with an average annual production of 14.5 MT in the period 2006 to 2013 (Defra, 2018). Adepidyn is a novel succinate dehydrogenase inhibitor (SDHI) fungicide having activity against Fusarium species, which other SDHIs do not have. A field experiment was conducted in four randomised blocks of winter wheat. The experimental plot was inoculated with Fusarium graminearum in the spring followed by mist irrigation during flowering. Plots were treated with various treatments including Adepidyn and the current industry standard fungicide, Proline (Bayer CropScience, Leverkusen, Germany) at half and full rates, or left untreated at early flowering. At harvest, yield was determined and the grain was milled and analysed for DON concentration using ELISA (Agraquant; Romer Labs, Getzersdorf, Austria). With the use of the Adepidyn fungicide to control FHB, a reduction of $80 \%$ in levels of DON compared to untreated wheat was achieved. Furthermore, a reduction of 54\% in levels of DON, compared to the use of the standard fungicide Proline, in wheat kernels at harvest was expected to be achieved. 
Case 2. Pre-harvest - use of resistant maize cultivars and/or biocontrol

Two pre-harvest strategies for aflatoxin mitigation in maize were investigated in Serbia during the MyToolBox project: the use of Aspergillus resistant maize cultivars and the use of locally isolated atoxigenic Aspergillus flavus strains (referred to as biocontrol). Maize is the most cultivated crop in Serbia, with on average a yield of 6.1 MT per year (Eurostat, 2019). The susceptibility of 50 maize hybrids belonging to different FAO maturity groups was evaluated in 2016. In these trials, 20 maize hybrids were selected for subsequent screening in 2017 and 2018, performed at one location (Sombor, Serbia). Susceptibility was evaluated based on visual assessment of ears showing Aspergillus rot symptoms and subsequent analysis of aflatoxin contamination in maize kernels at harvest. With the use of resistant maize cultivars, a reduction of aflatoxin contamination between 62 and $82 \%$ was achieved without a loss in yield (Budakov et al., 2019).

The biocontrol trials within MyToolBox were performed at three different locations in Serbia, in Bečej and Sombor (in 2016, 2017 and 2018) and Uljma (in 2018). The atoxigenic A. flavus strain (MyToolBox AF01) was applied at the stage of the presence of ten true leaves of maize plants grown under commercial conditions. To test the biocontrol efficacy of the atoxigenic strain, the incidence of ears expressing Aspergillus rot symptoms was visually evaluated prior to harvest, and the aflatoxin contamination levels of the maize kernels were determined after harvest using an ELISA method. With the use of biocontrol, a reduction of aflatoxin contamination between 51 and $83 \%$ was achieved without a loss in yield (Savic et al., 2020).

\section{Case 3. Post-harvest - improved silo management}

The first proposed post-harvest strategy was to improve silo monitoring of stored cereals (wheat, barley and maize) with real-time sensors, which were ATEX compliant, which measured the key abiotic parameters $\mathrm{CO}_{2}$, temperature and relative humidity $(\mathrm{RH})$, coupled to a decision support system (DSS). In the UK, 21.9 MT of cereals, mainly wheat, barley and oats, were produced on average per year between the year 2009 and 2018 (DEFRA, 2018). About 30\% of this crop is stored in silos suitable for installing the real-time sensors measuring temperature, $\mathrm{RH}$ and $\mathrm{CO}_{2}$ level. The other $70 \%$ of the cereals is stored in barns and warehouses. In years with wet autumns, poor harvesting conditions and/ or the use of ambient drying systems can result in the upper layers of cereals becoming moist allowing mould spoilage and mycotoxin contamination to occur. This can lead to $5-10 \%$ losses of the stored grains, resulting in rejection of the grain for food use and sometimes even for feed use (McMullen et al., 2012; Savary et al., 2012; Scherm et al., 2013; Streit et al., 2013). In wheat and barley, the mycotoxin ochratoxin A (OTA) is mostly responsible for these losses due to poor storage. In maize, aflatoxins and fumonisins cause losses of up to $10 \%$ because of delays in drying or poor storage.

By having $\mathrm{CO}_{2}$ indicators integrated with relative humidity $(\mathrm{RH})$ and temperature sensors installed in silos, and coupled to a DSS, it is possible to link the physical real time data to biological boundary models for moisture content and temperature conditions (un)favourable for growth of specific mycotoxigenic fungal species in a specific cereal type and the associated mycotoxin production. Measuring of $\mathrm{CO}_{2}$ was demonstrated to be a more sensitive and an earlier indicator of initiation of mould spoilage activity and potential for increased mycotoxin presence than temperature and intergranular RH alone (Garcia-Cela et al., 2019). Such a real-time system allows the identification of the area within a silo which may represent a hot spot and improve pro-active post-harvest management of staple cereals to take remedial action, and is expected to reduce losses of food and feed chains by up to $50 \%$.

\section{Case 4. Post-harvest - innovative milling strategies}

The second proposed post-harvest measure was innovative milling of durum wheat. Italy is the largest producer of durum wheat in Europe. Between the years 2009 and 2018, almost $50 \%$ of the durum wheat produced in Europe, equal to an annual average of 4.2 MT, was produced in Italy (Eurostat, 2019). Based on a literature and patents review executed along the MyToolBox project tasks, potential pilot and industrial scale technologies were identified that minimise DON contamination and increase fibre content of wheat bran. Several configurations of optical sorting/ cleaning machines were tested in the cleaning phase of the milling process. In the milling phase, two different milling technologies (micronizer and hammer mill) and two different sieving technologies (traditional sieving and turboseparation) were tested (Khatibi et al., 2014; Ríos et al., 2009; Visconti et al., 2004). Overall, after cleaning and optical sorting, the results for the secondary debranning steps demonstrated that: hammer milling technology produced a finer micronization, which positively affected the separation of grain tissues with different mycotoxin and fibre levels. The larger particles size fractions of finest milled flour had the lowest DON/fibre ratio. The best solution to fractionate the larger particles (with lower DON/fibre ratio) was by sieving.

When milling durum wheat, the bran and other by-products represent around $22 \%$ of the entire wheat kernel. With a traditional milling procedure of durum wheat, around two thirds of this bran and other by-products cannot be used as raw material for food due to either micronutrients presence or DON contamination. It was estimated that up to $15-20 \%$ of the bran and other by-products that could not be used as raw material with a traditional milling procedure, could be 
used for human consumption when applying the innovative milling procedure (M. Suman, personal communication).

\section{Case 5. Safe use options}

A safe use option, applied in the MyToolBox project, was the use of mycotoxin degrading enzymes during the process of bioethanol and subsequent production of distiller's dried grains with solubles (DDGS). In 2016, 4.7 MT of DDGS were produced in Europe (OECD, 2017). Raw materials with mycotoxin contamination higher than legally allowed in feed might be used as biomass in ethanol, and thus DDGS production. However, this high mycotoxin contamination impacts the fermentation and mycotoxins are concentrated (up to three times) in the DDGS preventing it from use as feed. The use of degrading enzymes in the production process would optimise the fermentation process and results in DDGS that fulfil EU guidance limits for mycotoxins in feed (EC, 2006a).

Laboratory scale $(450 \mathrm{ml})$ experiments were carried out to evaluate the efficacy of two mycotoxin degrading enzymes, FUMzyme ${ }^{\bullet}$ and ZENzyme ${ }^{\bullet}$ (Biomin, Tulln, Austria), to degrade fumonisin $\mathrm{B}_{1}\left(\mathrm{FB}_{1}\right)$ and zearalenone (ZEN) in the bioethanol production process. When FUMzyme $(60 \mathrm{U} / \mathrm{kg}$ maize) was included in the fermentation, $3 \%$ of the initial $\mathrm{FB}_{1}$ level was detected in the mash. Similarly, the addition of ZENzyme (40 U/kg maize) during fermentation resulted in a detection of $11 \%$ of the initial ZEN level. Subsequently, the mycotoxin degrading enzymes were used in a pilot scale (60 l) experiment using naturally contaminated maize $\left(7,160 \mu \mathrm{g} / \mathrm{kg} \mathrm{FB}{ }_{1}, 4,670 \mu \mathrm{g} / \mathrm{kg} \mathrm{ZEN}\right)$. Results showed that addition of the enzyme FUMzyme led to all DDGS samples tested below the limit of quantification (LOQ) $(30 \mu \mathrm{g} / \mathrm{kg})$ for $\mathrm{FB}_{1}$. Moreover, the addition of the enzyme ZENzyme led to $>90 \%$ of the DDGS samples tested below the LOQ $(30 \mu \mathrm{g} / \mathrm{kg})$ for ZEN.

\section{Methods for assessing the impact of the control strategies}

The impact of each prevention or control measure described above was estimated for each case. The effects of the control strategy on mycotoxin contamination were estimated, for both the test region and extrapolated to the European region, where appropriate. For Cases 3, 4 and 5, the impact on the reduction in waste was also included. For each case, the effect of the prevention or control measure was compared to its baseline situation.

All assessments started with a baseline situation for mycotoxin contamination, and the respective annual crop production, either in the test region, or the relevant European area, in tonnes (Table 1 and 2). Monte Carlo simulation models were developed in R, version 3.5.0, and 10,000 model iterations were run for each case. For each model iteration, one year was chosen with the accompanying mycotoxin concentrations observed in that year. The results are presented as distributions, showing the range and probability of possible outcomes due to the uncertainty of the input data as well as the annual differences in mycotoxin concentrations observed and the amount of cereals produced. For each control or prevention measure, three scenarios were defined, related to the different levels of uptake of the proposed control measures - either 20, 50 and $80 \%$ - of the farmers or producers applying the particular measure.

\section{Cases 1 and 2. Pre-harvest control measures}

For Case 1, the use of the Adepidyn fungicide to mitigate DON in wheat, the modelling resulted in the percentage of wheat as well as the number of tonnes of wheat suitable as (milling) wheat for food use for each scenario, using the EU legal limit of $1,250 \mu \mathrm{g} / \mathrm{kg}$ for unprocessed cereals other than durum wheat, oats and maize (EC, 2006b). For Case 2 , the use of resistant maize cultivars and/or biocontrol, the model estimated the percentages and the number of tonnes of maize in the following three classes: maize with a concentration below $5 \mu \mathrm{g} / \mathrm{kg}$ (representing the EU limit for compound feed for dairy cattle and calves), between 5 and $20 \mu \mathrm{g} / \mathrm{kg}$, and above $20 \mu \mathrm{g} / \mathrm{kg}$ aflatoxin $\mathrm{B}_{1}\left(\mathrm{AFB}_{1}\right)$ (EU, 2002). Since almost all maize produced in Serbia is used for feed, data for food production were not retrieved.

Input data for Cases 1 and 2 included distributions of the annual concentration of DON in wheat in the UK (adapted from Edwards and Jennings, 2018) and of $\mathrm{AFB}_{1}$ in maize in Serbia (confidential data), as well as the total volume (in tonnes) of wheat produced in the UK (retrieved from DEFRA, 2018) and maize produced in Serbia (retrieved from Eurostat, 2019), respectively. After estimating the impact for produce in both these countries, the estimated impact was extrapolated to relevant European region. For Case 1, wheat production in the sub-regions Northern, Central and Southern Europe were involved. Case 2 aimed at Central and Southern Europe. Data on mycotoxin contamination of wheat and maize in these sub-regions in Europe were kindly provided by BIOMIN (confidential data). The annual production data of wheat and maize for the sub-regions of Europe were retrieved from Eurostat (2019). The EU legal (guidance) limits on mycotoxins in place to define the categorisation of the use of crops for food, feed and waste, and finally the expected reduction that can be achieved with the proposed control measure were used as input data as well (Table 1).

\section{Cases 3, 4 and 5. Post-harvest control measures}

For Cases 3, 4, and 5 the model was used to estimate the percentage of reduction in losses where the mycotoxin concentrations were above the legal limits for cereals, bran, or maize and/or DDGS compared to the baseline existing losses. Input data for the post-harvest measures were similar 
Table 1. Input parameters and data to estimate the impact of the pre-harvest measures.

\begin{tabular}{|c|c|c|}
\hline Variable & Data available & Source \\
\hline \multicolumn{3}{|l|}{ Case 1} \\
\hline Wheat production UK 2006-2013 & $\begin{array}{l}\text { Tonnes/year } \\
\text { Mean: } 11,921,000\end{array}$ & DEFRA, 2018 \\
\hline Deoxynivalenol (DON) contamination wheat UK 2006-2013 & $4.1 \%$ samples above $1,250 \mu \mathrm{g} / \mathrm{kg}$ & Edwards and Jennings, 2018 \\
\hline Wheat production Europe ${ }^{1} 2013-2019$ & $\begin{array}{l}\text { Tonnes/country/year } \\
\text { (Northern: mean: 29,313,000; } \\
\text { Central: mean: 103,897,000; } \\
\text { Southern: mean: 42,157,000) }\end{array}$ & Eurostat, 2019 \\
\hline DON contamination wheat Europe ${ }^{1}$ 2013-2019: & $\%$ positive samples & Confidential data, BIOMIN \\
\hline Northern Europe & $1^{\text {st }}$ Quartile & \\
\hline Central Europe & Median & \\
\hline Southern Europe & $\begin{array}{l}3^{\text {rd }} \text { Quartile } \\
95^{\text {th }} \text { Percentile } \\
\text { Maximum }\end{array}$ & \\
\hline Expected reduction in DON concentration with Adepidyn ${ }^{\top \mathrm{TM}}$ & $54 \%$ & $\begin{array}{l}\text { Personal communication, } \\
\text { Prof. S.G. Edwards, Harper } \\
\text { Adams University }\end{array}$ \\
\hline $\begin{array}{l}\text { EU limit DON in food - unprocessed cereals (excluding rice, durum } \\
\text { wheat, oats, maize) }\end{array}$ & $1,250 \mu \mathrm{g} / \mathrm{kg}$ & EC, 2006b \\
\hline EU limit DON in food - unprocessed durum wheat and oats & $1,750 \mu \mathrm{g} / \mathrm{kg}$ & EC, $2006 \mathrm{~b}$ \\
\hline $\begin{array}{l}\text { EU limit DON in food - unprocessed maize, with the exception of } \\
\text { unprocessed maize intended to be processed by wet milling }\end{array}$ & $1,750 \mu \mathrm{g} / \mathrm{kg}$ & $E C, 2006 b$ \\
\hline \multicolumn{3}{|l|}{ Case 2} \\
\hline Maize production Serbia 2012-2016 & $\begin{array}{l}\text { Tonnes/year } \\
\text { Mean: } 6,036,000\end{array}$ & Eurostat, 2019 \\
\hline Aflatoxin contamination maize Serbia 2012-2016 & $\begin{array}{l}\text { Lognormal distributions fitted on } \\
\text { concentration data per year }\end{array}$ & Raw data are confidential data \\
\hline Maize production Europe ${ }^{1} 2013-2018$ & $\begin{array}{l}\text { Tonnes/country/year } \\
\text { (Central: mean: 50,362,000; } \\
\text { Southern mean: 30,013,000) }\end{array}$ & Eurostat, 2019 \\
\hline Aflatoxin contamination maize Europe ${ }^{1} 2013-2018$ & $\%$ positive samples & Confidential data, BIOMIN \\
\hline Central Europe & $1^{\text {st }}$ Quartile & \\
\hline Southern Europe & $\begin{array}{l}2^{\text {nd }} \text { Quartile } \\
3^{\text {rd }} \text { Quartile } \\
95^{\text {th }} \text { Percentile } \\
\text { Maximum }\end{array}$ & \\
\hline Expected reduction with the use of resistant cultivars & $62-82 \%$ & Budakov et al., 2019 \\
\hline Expected reduction with the use of biocontrol & $51-83 \%$ & Savic et al., 2020 \\
\hline EU limit aflatoxin $B_{1}$ - feed materials & $20 \mu \mathrm{g} / \mathrm{kg}$ & EC, 2002 \\
\hline EU limit aflatoxin $B_{1}$ - compound feed for dairy cattle and calves & $5 \mu \mathrm{g} / \mathrm{kg}$ & EC, 2002 \\
\hline
\end{tabular}

to the input data used for the pre-harvest measures. Baseline data were available on: the production of cereals in the UK, durum wheat in Italy and in Europe, and maize in Europe, the estimated $\mathrm{ZEN}$ and $\mathrm{FB}_{1}$ contamination of the crops harvested from the respective sub-regions in Europe, and the benefits of the control measures in reducing losses due to mycotoxin contamination relative to the existing baseline losses (Table 2). For Cases 3 and 4, for each model 
Table 2. Input parameters and data to estimate the impact of the post-harvest measures.

\begin{tabular}{|c|c|c|}
\hline Variable & Data used & Source \\
\hline \multicolumn{3}{|l|}{ Case 3} \\
\hline Production cereals (wheat, barley and maize) in the UK 2009-2018 & $\begin{array}{l}\text { Tonnes/year } \\
\text { Mean }=21,890,000\end{array}$ & DEFRA, 2018 \\
\hline $\begin{array}{l}\text { Current post-harvest grain losses (baseline) due to ochratoxin } A \text { in } \\
\text { wheat and barley, and aflatoxins and fumonisins in maize }\end{array}$ & $5-10 \%$ & $\begin{array}{l}\text { McMullen et al., 2012; Savary et } \\
\text { al., 2012; Scherm et al., 2013; } \\
\text { Streit et al., } 2013\end{array}$ \\
\hline Cereals stored in silos in the UK & $30 \%$ & $\begin{array}{l}\text { Personal communication, Dr. } \\
\text { Garcia-Cela, Cranfield University }\end{array}$ \\
\hline $\begin{array}{l}\text { Expected reduction in post-harvest grain losses with the use of real- } \\
\text { time sensors in silos }\end{array}$ & $50 \%$ & $\begin{array}{l}\text { McMullen et al., 2012; Savary et } \\
\text { al., 2012; Scherm et al., 2013; } \\
\text { Streit et al., } 2013\end{array}$ \\
\hline \multicolumn{3}{|l|}{ Case 4} \\
\hline Production durum wheat in Italy $2009-2018$ & $\begin{array}{l}\text { Tonnes/year } \\
\text { Mean }=4,197,000\end{array}$ & Eurostat, 2019 \\
\hline Production durum wheat in Europe 2009-2018 & $\begin{array}{l}\text { Tonnes/year } \\
\text { Mean }=8,841,000\end{array}$ & Eurostat, 2019 \\
\hline Percentage of bran in durum wheat & $22 \%$ & $\begin{array}{l}\text { Personal communication, } \\
\text { Dr. M. Suman, Barilla }\end{array}$ \\
\hline $\begin{array}{l}\text { Percentage of bran after traditional milling that cannot be used for food } \\
\text { (baseline) }\end{array}$ & $33 \%$ & $\begin{array}{l}\text { Personal communication, } \\
\text { Dr. M. Suman, Barilla }\end{array}$ \\
\hline Percentage of bran saved with innovative milling & $15-22 \%$ & Pilot study, MyToolBox \\
\hline \multicolumn{3}{|l|}{ Case 5} \\
\hline Total production of maize in Europe ${ }^{1} 2013-2018$ & $\begin{array}{l}\text { Tonnes/sub-region/year } \\
\text { Northern: mean:179,000; } \\
\text { Central: mean: 47,836,000; } \\
\text { Southern: mean: } 32,165,000\end{array}$ & Derived from: Eurostat, 2019 \\
\hline $\begin{array}{l}\text { Fumonisin } B_{1}+B_{2} \text { contamination maize used for bioethanol production } \\
\text { in Europe }{ }^{1} 2013-2018\end{array}$ & $\begin{array}{l}\% \text { positive samples } \\
1^{\text {st }} \text { Quartile }\end{array}$ & Confidential data, BIOMIN \\
\hline Northern Europe & $2^{\text {nd }}$ Quartile & \\
\hline Central Europe & $3^{\text {rd }}$ Quartile & \\
\hline Southern Europe & $\operatorname{Max}$ & \\
\hline $\begin{array}{l}\text { Zearalenol (ZEN) contamination of maize used for bioethanol } \\
\text { production in Europe }{ }^{1} 2013-2018\end{array}$ & $\begin{array}{l}\% \text { positive samples } \\
1^{\text {st }} \text { Quartile }\end{array}$ & Confidential data, BIOMIN \\
\hline Northern Europe & $2^{\text {nd }}$ Quartile & \\
\hline Central Europe & $3^{\text {rd }}$ Quartile & \\
\hline Southern Europe & Max & \\
\hline $\begin{array}{l}\text { Expected reduction in fumonisin } B_{1}+B_{2} \text { concentration with the use of } \\
\text { FUMzyme }{ }^{\circledR}\end{array}$ & $99 \%$ & Kotz et al., 2018 \\
\hline Expected reduction in ZEN concentration with the use of ZENzyme ${ }^{\circledR}$ & $89 \%$ & Kotz et al., 2018 \\
\hline $\begin{array}{l}\text { EU guidance limit fumonisin } B_{1}+B_{2} \text { in feed materials - maize and } \\
\text { maize products }\end{array}$ & $60,000 \mu \mathrm{g} / \mathrm{kg}$ & $E C, 2006 a$ \\
\hline EU guidance limit ZEN in feed materials - maize by-products & $3,000 \mu \mathrm{g} / \mathrm{kg}$ & EC, 2006a \\
\hline
\end{tabular}

\footnotetext{
1 The sub-region 'Northern Europe' consisted of the following countries: Denmark, Estonia, Finland, Ireland, Latvia, Lithuania, Norway, Sweden, United Kingdom. The sub-region 'Central Europe' consisted of the following countries: Austria, Belgium, Czech Republic, France, Germany, Hungary, Luxembourg, Poland, Romania, Slovakia, Slovenia, Switzerland, the Netherlands. The sub-region 'Southern Europe' consisted of the following countries: Bosnia and Herzegovina, Bulgaria, Croatia, Cyprus, Greece, Italy, Kosovo, Montenegro, North Macedonia, Portugal, Serbia, Spain, and Turkey.
} 
iteration, one year was chosen with its corresponding volume of crop produced. For each iteration, the volume of losses was determined based on the expected reduction in losses with the use of real-time sensors for Case 3 and the expected reduction in losses with the use of innovative milling for Case 4. For Case 3, since each country has different practices with regards to storage of cereals, and limited information was available for each country, extrapolation of the results found for the UK to Europe would lead to biased results and therefore was not modelled in this study.

For Case 5, for each model iteration, a single year was chosen with its corresponding sum (of $\mathrm{FB}_{1}$ and fumonisin $\mathrm{B}_{2}$ ) and $\mathrm{ZEN}$ contamination level, and maize production in tonnes. For each iteration, the number of tonnes of maize unsuitable for the production of ethanol/DDGS was determined without the use of degrading enzymes. Two cases were considered: firstly, it was assumed that maize with $\mathrm{FB}_{1}+\mathrm{FB}_{2}$ and $\mathrm{ZEN}$ concentrations above the EU legal limits for feed was not considered suitable for the production of DDGS, and second, it was assumed that mycotoxin levels in the DDGS were three times higher than in the original material, therefore, maize with $\mathrm{FB}_{1}$ and $\mathrm{ZEN}$ levels above one third of the EU legal limits for feed was not suitable for the production of DDGS.

\section{Results}

\section{Pre harvest. Use of a fungicide to control Fusarium head blight (Case 1)}

The results of the modelling outcome are presented in Table 3 and 4 and Figure 1. Table 3 presents the percentage, as well as the amount in tonnes of wheat suitable for human consumption with the different levels of uptake of the Adepidyn fungicide to control FHB instead of the standard fungicide Proline. In $50 \%$ of the scenarios, between 94 and $100 \%$ of the wheat produced in the UK would be suitable as milling wheat if $20 \%$ or more farmers would use the Adepidyn fungicide. In 50\% of the scenarios, between 96 and $100 \%$ of the wheat produced in the UK would be suitable as milling wheat if $80 \%$ or more farmers would use the Adepidyn fungicide. With an uptake of this control measure of 20,50 or $80 \%$, on average $42,000,129,000$, and 219,000 extra tonnes, respectively, could be available as milling wheat for human consumption in the UK.

When extrapolating these results to European regions, the impact of the use of the Adepidyn fungicide became larger. When $50 \%$ of the farmers in Europe would use the Adepidyn fungicide, in Northern Europe, on average an extra volume of 357,000 tonnes wheat per year could be used as milling wheat, instead of use as feed. In Central Europe, on average, an extra 3.8 MT wheat could be used as milling wheat and in Southern Europe, on average, an extra 1.1 MT wheat could be used as milling wheat. Table 4 presents the results
Table 3. Estimated average impact with the use of the Adepidyn $^{\mathrm{TM}}$ fungicide in the UK on the total volume of wheat suitable for milling in the UK, using DON concentrations for the years 2006-2013, as based on Edwards and Jennings, 2018.

\begin{tabular}{|c|c|c|}
\hline & Milling wheat (\%) & $\begin{array}{l}\text { Annual total volume } \\
\text { of milling }{ }^{1} \text { wheat in } \\
\text { tonnes } \times 1000\end{array}$ \\
\hline Baseline & 95.9 & $\begin{array}{l}13,733 \\
(12,679-14,268)\end{array}$ \\
\hline $\begin{array}{l}20 \% \text { of the farmers } \\
\text { use Adepidyn }\end{array}$ & $96.3(94-100)$ & $\begin{array}{l}13,775 \\
(12,465-14,878)\end{array}$ \\
\hline $\begin{array}{l}50 \% \text { of the farmers } \\
\text { use Adepidyn }\end{array}$ & $96.8(95-100)$ & $\begin{array}{l}13,862 \\
(12,598-14,878)\end{array}$ \\
\hline $\begin{array}{l}80 \% \text { of the farmers } \\
\text { use Adepidyn }\end{array}$ & $97.4(96-100)$ & $\begin{array}{l}13,952 \\
(12,731-14,878)\end{array}$ \\
\hline
\end{tabular}

for the sub-regions of Europe in terms of percentages and volume (tonnes) of wheat suitable as milling wheat. Figure 1 shows the entire distribution of the results.

\section{Pre harvest. Use of resistant maize cultivars and/or biocontrol (Case 2)}

With $20 \%$ of the farmers using one control measure, either resistant maize cultivars or biocontrol in Serbia, on average, $1.9 \%$ less maize with an $\mathrm{AFB}_{1}$ concentration above $20 \mu \mathrm{g} /$ $\mathrm{kg}$ is expected, as compared to the baseline in which none of these measures are applied (Table 5). With $50 \%$ of the farmers using one control measure, 4.9-5.6\% less maize would exceed the $\mathrm{AFB}_{1}$ concentration limit of $20 \mu \mathrm{g} / \mathrm{kg}$ in feed. With $80 \%$ of the farmers using one control measure, 8.3-9\% less maize with an $\mathrm{AFB}_{1}$ concentration $>20 \mu \mathrm{g} / \mathrm{kg}$ would be expected and 15.9-17.4\% more maize would have an $\mathrm{AFB}_{1}$ concentration $<5 \mu \mathrm{g} / \mathrm{kg}$ (Table 5).

If it was assumed that the use of biocontrol has the same effectiveness on resistant maize cultivars, and if $80 \%$ of the farmers would use both control measures, an average of $12.3 \%$ less maize would exceed the AFB 1 limit of $20 \mu \mathrm{g} / \mathrm{kg}$. This would be significant, equivalent to 545,000 tonnes of maize. In this situation, on average, $25.7 \%$, equivalent to 1.6 MT more maize, compared to the baseline, could be used for food use with an $\mathrm{AFB}_{1}$ concentration $<5 \mu \mathrm{g} / \mathrm{kg}$ in Serbia (Table 5).

With the use of pre-harvest measures against aflatoxin contamination of cereals in Europe, more maize would have a low $\mathrm{AFB}_{1}$ concentration and less would have an $\mathrm{AFB}_{1}$ concentration above the $\mathrm{EC}$ maximum limit for feed products. In Southern Europe, high concentrations of aflatoxins are often observed, and a high impact 
Table 4. Expected average impact of the use of Adepidyn ${ }^{\text {TM }}$ fungicide on the total volume of wheat suitable for milling in Europe. ${ }^{1}$

\begin{tabular}{|c|c|c|c|c|c|c|c|}
\hline & \multicolumn{2}{|c|}{ Northern Europe ${ }^{2}$} & \multicolumn{2}{|c|}{ Central Europe ${ }^{2}$} & \multicolumn{2}{|c|}{ Southern Europe ${ }^{2}$} & \multirow{2}{*}{$\begin{array}{l}\text { Total } \\
\text { Milling wheat } \\
\text { (MT tonnes) }\end{array}$} \\
\hline & $\begin{array}{l}\text { Milling wheat } \\
(\%)\end{array}$ & $\begin{array}{l}\text { Milling wheat } \\
(\times 1000 \text { tonnes })\end{array}$ & $\begin{array}{l}\text { Milling wheat } \\
(\%)\end{array}$ & $\begin{array}{l}\text { Milling wheat } \\
(\times 1000 \text { tonnes) }\end{array}$ & $\begin{array}{l}\text { Milling wheat } \\
(\%)\end{array}$ & $\begin{array}{l}\text { Milling wheat } \\
(\times 1000 \text { tonnes })\end{array}$ & \\
\hline Baseline & $92.3(84-100)$ & $\begin{array}{l}26,640 \\
(24,338-30,012)\end{array}$ & $83.9(81-88)$ & $\begin{array}{l}82,609 \\
(75,835-88,413)\end{array}$ & $93.5(90-99)$ & $\begin{array}{l}44,287 \\
(40,994-48,116)\end{array}$ & $154(147-158)$ \\
\hline $20 \%$ uptake & $92.9(85-100)$ & $\begin{array}{l}26,834 \\
(24,338-30,325)\end{array}$ & $85.5(82-89)$ & $\begin{array}{l}84,149 \\
(76,738-90,108)\end{array}$ & $94.5(91-99)$ & $\begin{array}{l}44,652 \\
(41,654-48,116)\end{array}$ & $156(149-163)$ \\
\hline $50 \%$ uptake & $93.7(87-100)$ & $\begin{array}{l}26,997 \\
(24,338-30,638)\end{array}$ & $87.7(85-92)$ & $\begin{array}{l}86,405 \\
(78,839-92,536)\end{array}$ & $95.9(93-99)$ & $\begin{array}{l}45,349 \\
(42,541-48,698)\end{array}$ & $159(152-166)$ \\
\hline $80 \%$ uptake & $94.7(89-100)$ & $\begin{array}{l}27,219 \\
(24,338-30,950)\end{array}$ & $89.9(87-94)$ & $\begin{array}{l}88,703 \\
(81,252-94,814)\end{array}$ & $97.4(96-100)$ & $\begin{array}{l}46,018 \\
(43,477-49,712)\end{array}$ & $162(155-170)$ \\
\hline
\end{tabular}

${ }^{1}$ Deoxynivalenol concentrations for the years $2013-2018$ were provided by BIOMIN. The values in brackets represent the $1^{\text {st }}$ and the $3^{\text {rd }}$ quartiles of the distribution.

2 The sub-region 'Northern Europe' consisted of the following countries: Denmark, Estonia, Finland, Ireland, Latvia, Lithuania, Norway, Sweden, United Kingdom. The sub-region 'Central Europe' consisted of the following countries: Austria, Belgium, Czech Republic, France, Germany, Hungary, Luxembourg, Poland, Romania, Slovakia, Slovenia, Switzerland, the Netherlands. The sub-region 'Southern Europe' consisted of the following countries: Bosnia and Herzegovina, Bulgaria, Croatia, Cyprus, Greece, Italy, Kosovo, Montenegro, North Macedonia, Portugal, Serbia, Spain, and Turkey.

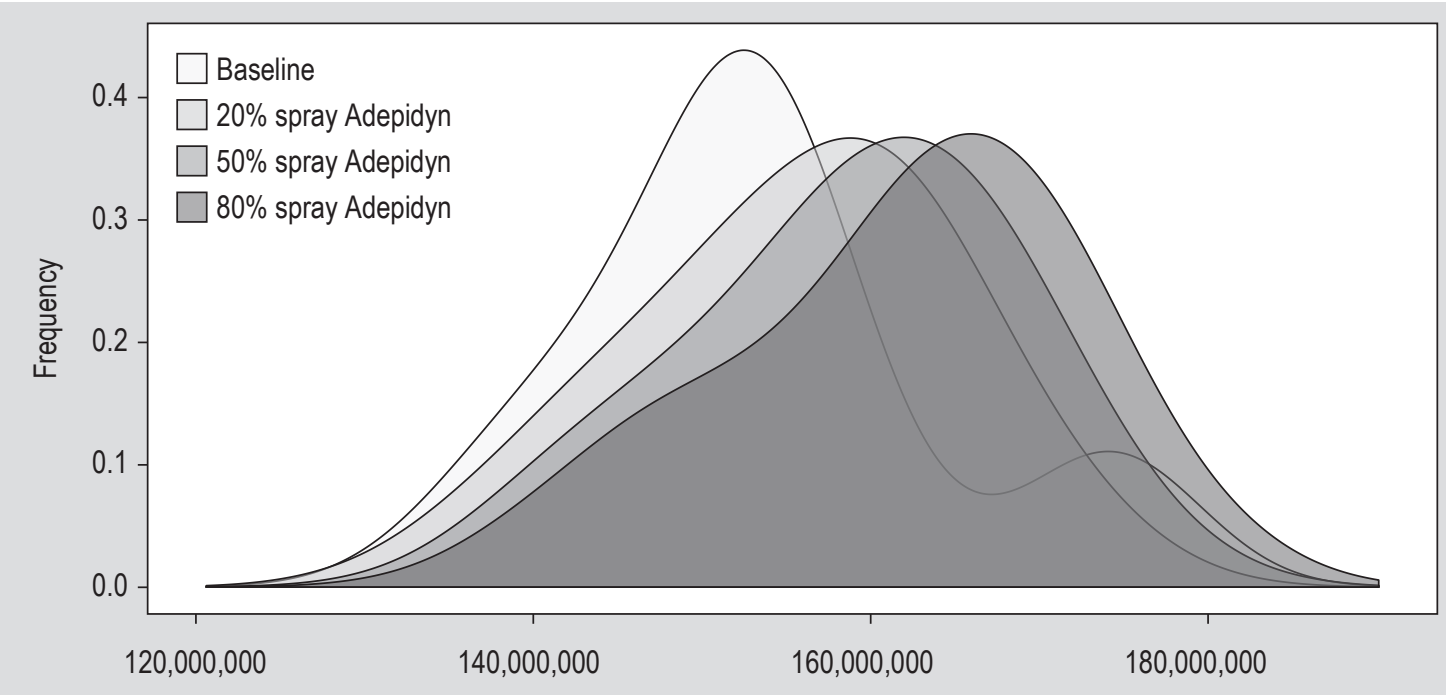

Estimated volume of wheat with deoxynivalenol concentration $<1,250 \mu \mathrm{g} / \mathrm{kg}$ (tonnes)

Figure 1. Estimated volume (tonnes) of milling wheat grown in Europe with deoxynivalenol concentrations $<1,250 \mu \mathrm{g} / \mathrm{kg}$ with the use of the Adepidyn ${ }^{\mathrm{TM}}$ fungicide to control Fusarium head blight instead of the standard fungicide Proline, at various levels of uptake $(20,50,80 \%)$.

would be expected with the use of such pre-harvest measures. With $80 \%$ of the farmers applying one of the two pre-harvest measure against aflatoxins, on average, an additional $2.4 \%$ of the maize cultivated would have an $\mathrm{AFB}_{1}$ concentration below $5 \mu \mathrm{g} / \mathrm{kg}$ in Europe (3.9\% more maize in Southern Europe and 1.4\% more maize in Central Europe). Furthermore, the total volume of maize grown in
Europe with an $\mathrm{AFB}_{1}$ concentration above $20 \mu \mathrm{g} / \mathrm{kg}$ would be reduced by $1.5 \%$ (this would be $3.1 \%$ in Southern Europe and $0.5 \%$ in Central Europe) (Table 6). Figure 2 shows the entire distributions of the impact of applying one of the two pre-harvest measures against $\mathrm{AFB}_{1}$ in terms of volume of maize with $\mathrm{AFB}_{1}$ concentrations above $20 \mu \mathrm{g} / \mathrm{kg}$, at different levels of uptake by the farmers $(20 \%, 50 \%$ or $80 \%)$. 
Table 5. Estimated average impact of the two pre-harvest measures against aflatoxins in maize in Serbia.

\begin{tabular}{|c|c|c|c|c|c|c|c|c|c|}
\hline & \multicolumn{3}{|c|}{$\begin{array}{l}\text { Impact with resistant cultivars } \\
(\% \text { and } \times 1000 \text { tonnes })\end{array}$} & \multicolumn{3}{|c|}{$\begin{array}{l}\text { Impact with atoxigenic strains } \\
\text { ( } \% \text { and } \times 1000 \text { tonnes) }\end{array}$} & \multicolumn{3}{|c|}{$\begin{array}{l}\text { Impact with resistant cultivars }+ \\
\text { atoxigenic strains ( } \% \text { and } \times 1000 \text { tonnes) }\end{array}$} \\
\hline & $<5 \mu \mathrm{g} / \mathrm{kg}$ & $5-20 \mu \mathrm{g} / \mathrm{kg}$ & $>20 \mu \mathrm{g} / \mathrm{kg}$ & $<5 \mu \mathrm{g} / \mathrm{kg}$ & $5-20 \mu \mathrm{g} / \mathrm{kg}$ & $>20 \mu \mathrm{g} / \mathrm{kg}$ & $<5 \mu \mathrm{g} / \mathrm{kg}$ & $5-20 \mu \mathrm{g} / \mathrm{kg}$ & $>20 \mu \mathrm{g} / \mathrm{kg}$ \\
\hline Baseline & $60.6 \%$ & $22.7 \%$ & $16.7 \%$ & $60.6 \%$ & $22.7 \%$ & $16.7 \%$ & $60.6 \%$ & $22.7 \%$ & $16.7 \%$ \\
\hline $20 \%$ uptake & $64.4 \%$ & $20.8 \%$ & $14.8 \%$ & $64.4 \%$ & $20.6 \%$ & $14.8 \%$ & $67.1 \%$ & $19.3 \%$ & $13.7 \%$ \\
\hline (tonnes $\times 1000$ ) & 4,229 & 1,117 & 660 & 4,249 & 1,119 & 664 & 4,376 & 1,047 & 616 \\
\hline $50 \%$ uptake & $71.4 \%$ & $17.4 \%$ & $11.1 \%$ & $70.1 \%$ & $17.8 \%$ & $11.8 \%$ & $76.8 \%$ & $14.2 \%$ & $9.0 \%$ \\
\hline (tonnes × 1000 ) & 4,639 & 906 & 491 & 4,559 & 943 & 525 & 4,900 & 748 & 402 \\
\hline $80 \%$ uptake & $78.0 \%$ & $14.3 \%$ & $7.7 \%$ & $76.5 \%$ & $15.1 \%$ & $8.4 \%$ & $86.3 \%$ & $9.2 \%$ & $4.4 \%$ \\
\hline (tonnes $\times 1000$ ) & 5,014 & 708 & 334 & 4,849 & 755 & 372 & 5,382 & 458 & 195 \\
\hline
\end{tabular}

Table 6. Estimated average impact in terms of percentage and/or volume (tonnes) of implementing one of two presented preharvest measures against aflatoxins in maize in Europe. ${ }^{1}$

\begin{tabular}{|c|c|c|c|c|c|}
\hline & Impact & Baseline & $20 \%$ uptake & $50 \%$ uptake & $80 \%$ uptake \\
\hline \multirow[t]{4}{*}{ Central Europe ${ }^{2}$} & $<5 \mu \mathrm{g} / \mathrm{kg}(\%)$ & 96.6 & 96.9 & 97.5 & 98.0 \\
\hline & $5-20 \mu \mathrm{g} / \mathrm{kg}(\%)$ & 2.1 & 1.9 & 1.5 & 1.1 \\
\hline & $>20 \mu \mathrm{gg} / \mathrm{kg}(\%)$ & 1.3 & 1.2 & 1.0 & 0.8 \\
\hline & $>20 \mu \mathrm{g} / \mathrm{kg}$ (tonnes ×1000) & $552(0-905)$ & $508(0-905)$ & $437(0-808)$ & $362(0-459)$ \\
\hline \multirow[t]{4}{*}{ Southern Europe ${ }^{2}$} & $<5 \mu \mathrm{g} / \mathrm{kg}(\%)$ & 88.9 & 90.0 & 91.4 & 92.8 \\
\hline & $5-20 \mu \mathrm{g} / \mathrm{kg}(\%)$ & 5.7 & 5.5 & 5.3 & 5.0 \\
\hline & $>20 \mu \mathrm{g} / \mathrm{kg}(\%)$ & 5.3 & 4.5 & 3.4 & 2.2 \\
\hline & $>20 \mu \mathrm{g} / \mathrm{kg}$ (tonnes ×1000) & $1,667(1,071-2,200)$ & $1,432(947-1,894)$ & $1,061(631-1,572)$ & $683(314-981)$ \\
\hline \multirow[t]{4}{*}{ Central + Southern Europe } & $<5 \mu \mathrm{g} / \mathrm{kg}(\%)$ & 93.5 & 94.1 & 95.0 & 95.9 \\
\hline & $5-20 \mu \mathrm{g} / \mathrm{kg}(\%)$ & 3.6 & 3.4 & 3.0 & 2.7 \\
\hline & $>20 \mu \mathrm{g} / \mathrm{kg}(\%)$ & 2.9 & 2.5 & 1.9 & 1.4 \\
\hline & $>20 \mu \mathrm{g} / \mathrm{kg}$ (tonnes × 1000) & $2,218(1,307-2,942)$ & $1,940(1,071-2,593)$ & $1,498(670-2,087)$ & $1,045(335-1,578)$ \\
\hline
\end{tabular}

\section{Post-harvest. Improved silo management (Case 3)}

In the UK, with $20 \%$ of the silo managers using the real time sensors measuring the temperature, the RH and the $\mathrm{CO}_{2}$ levels, in silos suitable for these sensors, coupled to a DSS, on average $2.9 \%$ of the losses of wheat can be avoided annually. With half of the silo managers using the real-time sensors coupled to a DSS, these average annual losses can be reduced by $7.4 \%$, and with $80 \%$ uptake, $11.8 \%$ of the harvested product could be saved. This latter reduction of $11.8 \%$ is equivalent to 193,000 tonnes of cereals (Table 7; Figure 3). The expected impact for Europe would be the same in terms of percentages of reduction. When considering Europe as a whole, the volume of cereals produced is higher, so the losses due to mycotoxin contamination are also larger. However, each country has different practices with regards to storage of cereals and, therefore, extrapolating the results found for the UK to Europe would lead to biased results and was not modelled here.

If the scenario in which $100 \%$ of the harvested cereals are stored in silos is considered, which could, for example, be the case for large food and feed producers who store the cereals on-site, the expected reduction in losses would be on average $10.1 \%$, with $20 \%$ of the silos equipped with the sensors and a DSS, to on average $39.7 \%$,with $80 \%$ of the silos equipped with the sensors and a DSS. Table 8 presents more details. 


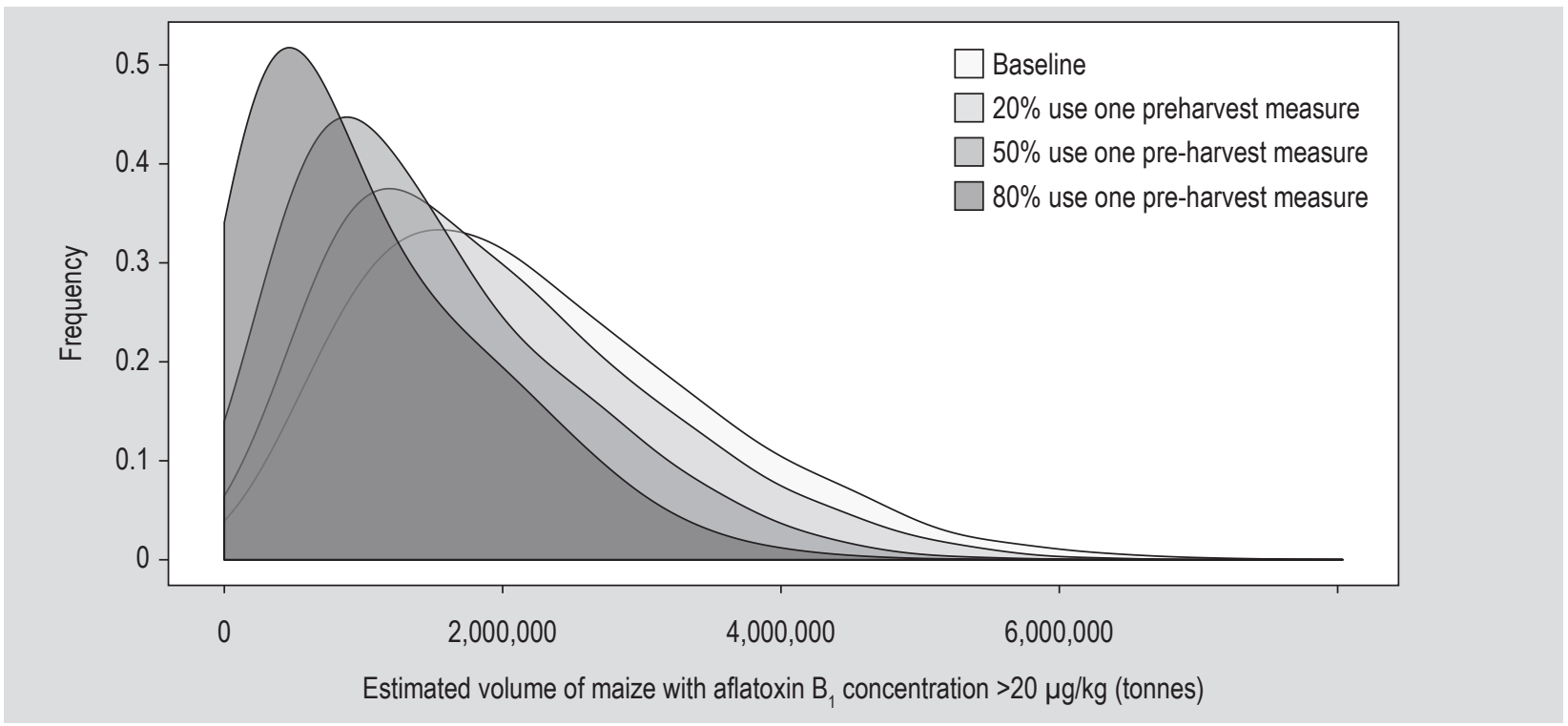

Figure 2. Estimated volume (tonnes) of maize grown in Europe with aflatoxin $B_{1}$ concentrations $>20 \mu \mathrm{g} / \mathrm{kg}$ (waste) at various levels of uptake of either resistant maize cultivars or biocontrol $(20,50,80 \%)$.

Table 7. Estimated average reduction in cereal losses with the use of real-time sensors coupled to decision support system (DSS) in silos in the UK. ${ }^{1}$

\begin{tabular}{lll} 
& $\begin{array}{l}\text { UK losses } \\
(\times 1000 \text { tonnes })\end{array}$ & $\begin{array}{l}\text { Reduction in } \\
\text { losses }(\%)\end{array}$ \\
Baseline & $1,638(1,373-1,916)$ & - \\
$20 \%$ use sensors with DSS & $1,590(1,319-1,849)$ & 2.9 \\
$50 \%$ use sensors with DSS & $1,517(1,253-1,763)$ & 7.4 \\
$80 \%$ use sensors with DSS & $1,445(1,197-1,679)$ & 11.8 \\
\hline
\end{tabular}

${ }^{1}$ The values in brackets represent the $1^{\text {st }}$ and $3^{\text {rd }}$ quartiles of the distribution.
Table 8. Average reduction in losses with using real-time sensors coupled to a decision support system (DSS) if all cereals produced in an area would be stored in silos. ${ }^{1}$

\begin{tabular}{ll} 
& Reduction in losses (\%) \\
$20 \%$ use sensors coupled to DSS & $10.1(0-25.7)$ \\
$50 \%$ use sensors coupled to DSS & $24.6(0-38)$ \\
$80 \%$ use sensors coupled to DSS & $39.7(30-50)$ \\
\hline${ }^{1}$ The values in brackets represent the $1^{\text {st }}$ and $3^{\text {rd }}$ quartiles.
\end{tabular}

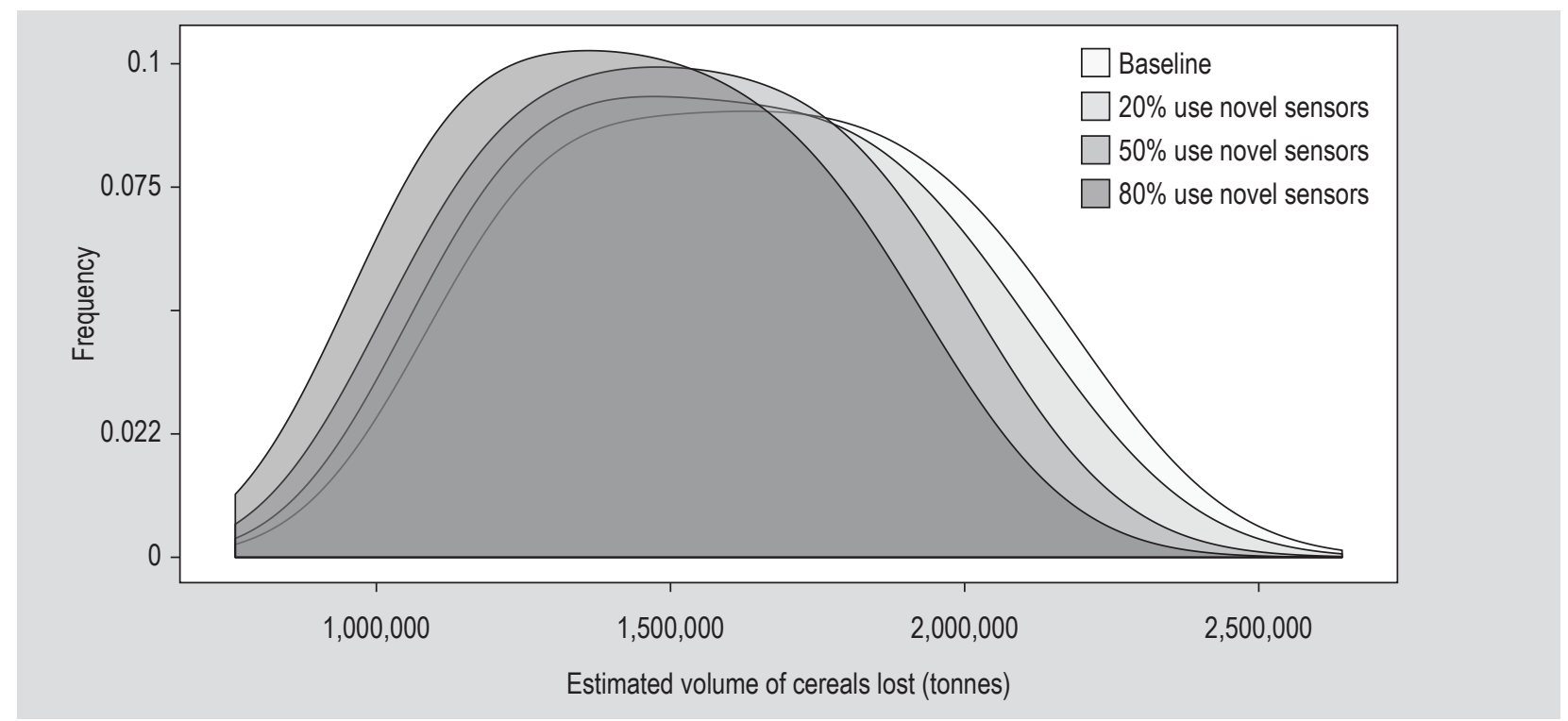

Figure 3. Estimated volume (tonnes) of cereals grown in the UK, lost due to spoilage with fungi and/or mycotoxins, without and with real-time sensors, at various levels of uptake $(20,50,80 \%)$. 


\section{Post-harvest. Innovative milling strategies (Case 4)}

Considering a ten year period (2009-2018), with 20\% of the processors using the innovative milling technique developed, 3.4\% of current losses of bran can be avoided on average per year; this is equivalent to 21,000 tonnes for Italy and 45,000 tonnes for the relevant European region. With half of the processors using this innovative milling technique, $8.6 \%$ of the losses can be avoided on average per year, equivalent to 53,000 tonnes in Italy and 113,000 tonnes for the relevant European region. With $80 \%$ of the processors using this innovative milling technique, 13.8\% of the losses can be avoided, equivalent to 85,000 tonnes of bran saved for Italy and 183,000 tonnes of bran saved for the relevant European region per year. Table 9 and Figure 4 . present more detailed results.

\section{Post-harvest. Safe-use options (Case 5)}

Considering that the concentrations of $\mathrm{FB}_{1}+\mathrm{FB}_{2}$ and ZEN would be three times higher in the DDGS than in the raw maize, on average $8.9 \%$ of the maize produced in Europe per year would currently not be suitable for the production of DDGS between the years 2009-2018, with 11.9\% in Central Europe and 0\% in Eastern Europe. In Europe, for the years 2009-2018, on average, 2.8 MT of maize per year exceeds the EU limits for feed for $\mathrm{FB}_{1}+\mathrm{FB}_{2}$ and/or ZEN and on average, 7.5 MT of maize per year exceeds one third of the EU limits (Table 10). Considering the scenario that all maize with $\mathrm{ZEN}$ and $\mathrm{FB}_{1}+\mathrm{FB}_{2}$ above the EU legal limits for feed would be used for the production of bioethanol, and assuming that of the raw maize used for the production of (bio)ethanol, about 30\% DDGS is produced, on average 0.8 MT of DDGS would not be suitable as feed, with a median of $0 \mathrm{MT}$, a $3^{\text {rd }}$ quartile of $1.7 \mathrm{MT}$ and a $95^{\text {th }}$ percentile of 3.7 MT (Table 10).

The enzymes degrading $\mathrm{FB}_{1}+\mathrm{FB}_{2}$ and $\mathrm{ZEN}$ by 99 and $89 \%$, respectively, all maize having $\mathrm{FB}_{1}+\mathrm{FB}_{2}$ and/or ZEN levels initially above the $\mathrm{EU}$ limits for $\mathrm{FB}_{1}+\mathrm{FB}_{2}$ and/or $\mathrm{ZEN}$ for feed, could be used to produce bioethanol and DDGS, safe to be used as feed. On average 2.8 MT maize produced in Europe per year exceeds the EU limits for feed for $\mathrm{FB}_{1}$ $+\mathrm{FB}_{2}$ and/or ZEN. These can now be used to produce DDGS, reducing these mycotoxin levels to below the EU limits for feed.

Table 9. Estimated average losses per year when milling durum wheat (baseline) in Italy and in Europe, and the reduction in losses with the use of innovative milling, at three different levels of uptake. ${ }^{1}$

$\begin{array}{llll} & \text { Italy losses (tonnes } \times 1000) & \text { Europe losses (tonnes } \times 1000) & \text { Reduction losses }(\%) \\ \text { Baseline } & 615(571-659) & 1,297(1,240-1,354) & 0 \\ 20 \% \text { use innovative milling } & 594(553-637) & 1,252(1,197-1,305) & 3.4 \\ 50 \% \text { use innovative milling } & 562(523-603) & 1,184(1,132-1,234) & 8.6 \\ 80 \% \text { use innovative milling } & 530(490-567) & 1,114(1,067-1,164) & 13.8\end{array}$

${ }^{1}$ The values in brackets represent the $1^{\text {st }}$ and $3^{\text {rd }}$ quartiles of the distribution.

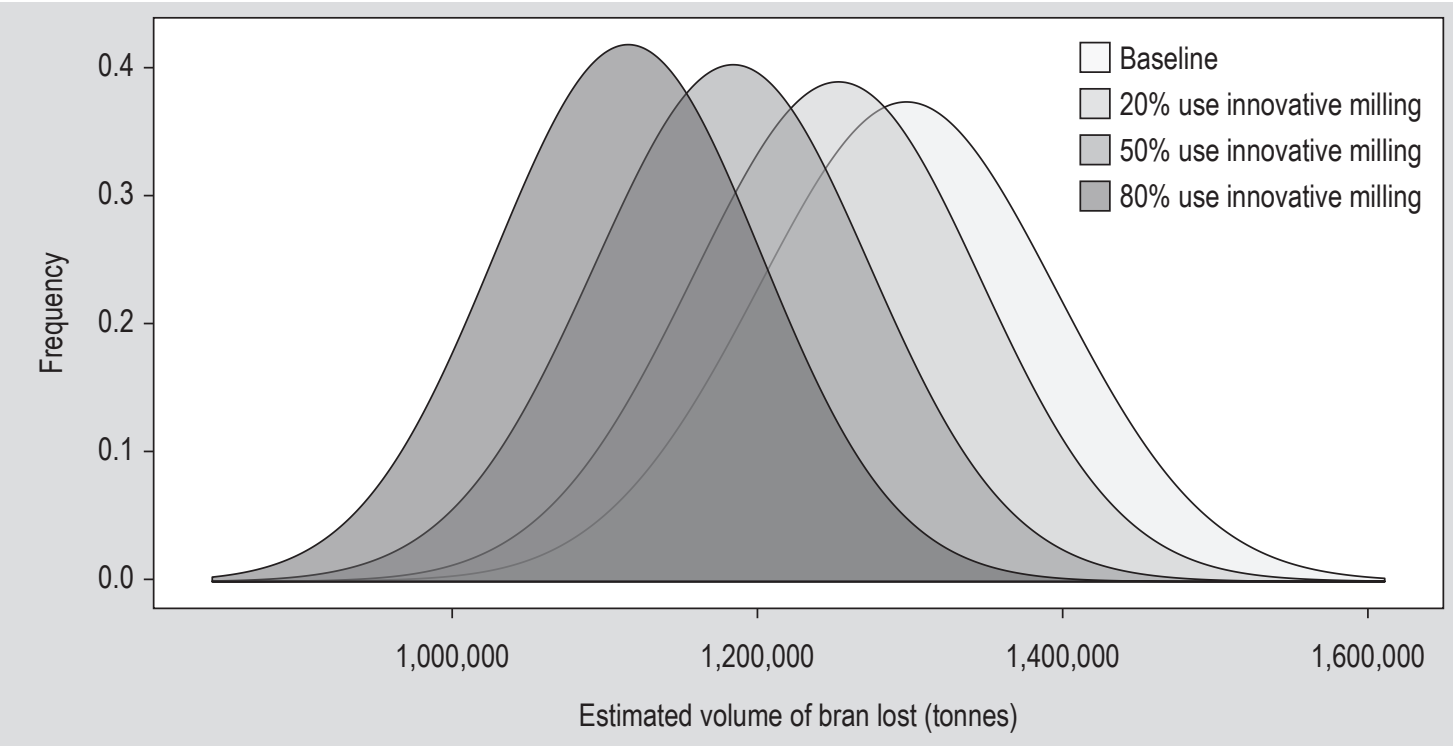

Figure 4. Estimated volume (tonnes) of bran lost in Europe, due to deoxynivalenol contamination, after milling of durum wheat without and with the use of the innovative milling technique, at various levels of uptake $(20,50,80 \%)$. 
Table 11. Reduction of losses (\%) and increase in volume of crops (tonnes) suitable as food in case of $50 \%$ uptake of the different control measures by the actors.

\begin{tabular}{|c|c|c|c|c|}
\hline \multirow[t]{2}{*}{ Case } & \multicolumn{2}{|l|}{ Reduced losses } & \multicolumn{2}{|c|}{ Increased food/feed } \\
\hline & Test-country & Europe & Test-country & Europe \\
\hline \multicolumn{5}{|l|}{ Pre-harvest } \\
\hline \multicolumn{5}{|l|}{ Case 1} \\
\hline Fungicides & - & - & $0.9 \%$ & $3 \%$ \\
\hline Deoxynivalenol/wheat & & & 129,000 tonnes & $5,000,000$ tonnes \\
\hline \multicolumn{5}{|l|}{ UK } \\
\hline \multicolumn{5}{|l|}{ Case 2.1} \\
\hline Biocontrol & $4.9 \%$ & $1 \%$ & $9.5 \%$ & $1.5 \%$ \\
\hline Aflatoxins/maize & 296,000 tonnes & 720,000 tonnes & 575,000 tonnes & $1,080,000$ tonnes \\
\hline \multicolumn{5}{|l|}{ Serbia } \\
\hline \multicolumn{5}{|l|}{ Case 2.2} \\
\hline Resistant cultivars & $5.6 \%$ & $1 \%$ & $7 \%$ & $1.5 \%$ \\
\hline Aflatoxins/maize & 339,000 tonnes & 720,000 tonnes & 424,000 tonnes & $1,080,000$ tonnes \\
\hline \multicolumn{5}{|l|}{ Serbia } \\
\hline \multicolumn{5}{|l|}{ Post-harvest } \\
\hline \multicolumn{5}{|l|}{ Case 3} \\
\hline Silo management & $7.4 \%$ & Not enough data & Not enough data & Not enough data \\
\hline Moulds/cereals & $1,620,000$ tonnes & & & \\
\hline \multicolumn{5}{|l|}{ UK } \\
\hline \multicolumn{5}{|l|}{ Case 4} \\
\hline Innovative milling & $8.6 \%$ & $8.6 \%$ & Not enough data & Not enough data \\
\hline Deoxynivalenol/durum wheat & 53,000 tonnes & 113,000 tonnes & & \\
\hline Italy & & & & \\
\hline \multicolumn{5}{|l|}{ Case 5} \\
\hline Bioethanol/DDGS & - & $1.6 \%$ & - & \\
\hline Zearalenone/fumonisin $\mathrm{B} /$ maize & & $1,383,000$ tonnes & & $1,223,000$ tonnes DDGS \\
\hline Europe & & & & \\
\hline
\end{tabular}

resistant maize cultivars having a higher impact. The use of degrading enzymes prior to the production of bioethanol and DDGS is much larger in years where the maize has high fumonisin and ZEN concentrations. In seasons that favour low contamination with these mycotoxins, or in regions with low observed concentrations such as Northern or Eastern Europe, the impact could become negligible. The total longterm impact of the control measures will, therefore, depend on where and how often high mycotoxin concentrations occur. In this respect forecasting models to predict mycotoxin contamination, combined with a decision support system, such as the MyToolBox e-tool, will prove to be highly valuable to determine the most effective corrective management practices with highest impact for regions and years with a high probability of high mycotoxin concentrations.

For all five cases, the obtained distributions on the impact of the prevention and control measures have wide distributions, implying a wide variation in the range of effects. For the pre-harvest control measures, the impact largely depends on the annual mycotoxin contamination, which is a highly variable input parameter. Furthermore, the effects of the prevention and control measures are variable and uncertain, leading to wider distributions of the results. For example, for the use of the Adepidyn fungicide against DON in wheat, the difference between 
the $5^{\text {th }}$ and $95^{\text {th }}$ percentile is in the range of $5 \mathrm{MT}$ tonnes of wheat suitable as milling wheat, for the UK alone. For the use of biocontrol against aflatoxins in maize and/or the use of resistant maize cultivars, the result distribution is skewed. The skewed distributions show that it is more likely to have years with a low amount of maize exceeding the $20 \mu \mathrm{g} \mathrm{AFB}_{1} / \mathrm{kg}$ (in the order of $1 \mathrm{MT}$ ) for feed use. In contrast, in years with more significant amounts of maize exceeding this limit the benefits would be in the order of $4 \mathrm{MT}$.

For the post-harvest measures, the same trend is observed, with the impact of the control measure depending on several variable input parameters. For example, for the use of real-time sensors in storage silos, coupled to a DSS, the difference between the $1^{\text {st }}$ and $3^{\text {rd }}$ quartile of the result distribution for all scenarios in in the range of 500,000 tonnes, showing that expected losses are highly variable. For Case 4, the use of the innovative wheat milling technique, the difference between the $1^{\text {st }}$ and the $3^{\text {rd }}$ quartiles of the distribution is in the range of 100,000 tonnes for Europe. This spread largely depends on the (variable) annual wheat production. For Case 5, the use of degrading enzymes in the bioethanol production process, the difference between the $1^{\text {st }}$ and the $3^{\text {rd }}$ quartile of the distribution representing the maize unsuitable for DDGS production is $8 \%$, equivalent to 6.7 MT of maize. This large spread is largely influenced by the fumonisin and ZEN concentrations observed in a specific year.

Integrating predictive models for mycotoxin contamination in decision support systems with effective science based agro-management solutions based on impact, such as in the MyToolBox e-platform, will allow decision makers to apply the most effective control measures for the specific region and point in time. This will underpin food safety in the whole food supply chain thus increasing consumers trust in food safety and strengthening the EU competitive position.

The current impact assessment was based on input data obtained from the trials performed during the four-year MyToolBox project. This means that there are certain limitations related to the data used since the trails were carried out in one or more years and/or based on specific assumptions. In further research, this preliminary work, based on data collected during the MyToolBox project, should be validated by integrating data from multiple years and European sites. Results for Case 1 suffer the most from the data limitation, since the effect of the Adepidyn fungicide was based on a trial performed during one year at one site only. The effects of fungicides depend on the FHB infection level which varies per year and sites, and this will influence the levels of DON contamination. However, this novel SDHI fungicide presents a new chemistry with a better activity than currently available products. Therefore, presenting the possible impact, by adding uncertainty around the average result obtained, based on one trial year, provides valuable insights.

As an example of the effect of an assumption, we assumed for Case 4 that on average one third of the bran cannot be used for food and/or feed after traditional milling. This is, however, a measured average and large variations can be expected, which were unavailable for this study, and therefore not taken into account. Furthermore, data on mycotoxin concentration in the sub-regions of Europe was based on annual surveys performed by BIOMIN. Most likely, the BIOMIN surveys do not include highly contaminated samples which have been removed from the feed stream by grain traders, feed processors or feed mills. Considering these highly contaminated batches that have already been removed, the impact of the presented control measures could be higher for all cases if extrapolated across Europe.

A limited number of variables were considered in this study. For Cases 3 and 4, the use of real-time sensors coupled to a DSS in storage silos and the use of an innovative milling technique prior to the pasta making process, assumptions were made that the reduction in losses was independent of the initial mycotoxin concentration. The initial mycotoxin contamination level is important as this influences the relative reductions that can be achieved. If this would have been taken into account, the distribution results would have been wider, and more variable. For Case 5, the presence of $\mathrm{FB}_{1}+\mathrm{FB}_{2}$ and $\mathrm{ZEN}$ in DDGS used as pig feed lead to large economic losses for the swine industry. The use of degrading enzymes might, therefore, have an additional indirect impact, not considered in this study. However, on the other hand, this case only considered two mycotoxins and one commodity. The presence of other mycotoxins, such as aflatoxins, and other ingredients, such as wheat, are not considered and might also lead to DDGS being unsuitable for animal feed. Furthermore, only crops grown in Europe are considered in this study; also considering imported (contaminated) crops could lead to a larger impact on the post-harvest control measures resulting in significantly lower losses due to mycotoxins.

Another limitation of this study is that the results are presented in terms of extra volume (tonnes) available as food or in terms of reduction in losses instead of its monetary values. The costs of the different prevention and control measures were not considered. The reason for this is that costs highly depend on individual situations of actors in the chain implementing the measures, and costs are difficult to assess for such prevention and control measures. In addition, the economic value of different key cereals fluctuates almost monthly as it is depending on the market conditions. It is much easier to use the reduction in losses in terms of tonnage to cover this to economic value 
as and when required. Moreover, a cost-benefit analyses would be necessary for the implementation of the different new technologies developed in the MyToolBox project and their cost effectiveness in the context of the EU food safety and food security agenda.

\section{Conclusions}

This impact assessment provides quantitative evidence that the various developed prevention and control strategies in the MyToolBox project, substantially can reduce mycotoxin contamination in these key food/feed supply chains as well as reduce the losses of produce due to mycotoxin contamination. It was based on data collected in the four year European project; the impact assessment results may be validated in future research with more (future) data from more years and sites. The impact was quantified for different levels of uptake of the control measure in different geographic areas in Europe. Combined with predictive models for mycotoxin contamination, such as developed and integrated in the MyToolBox e-platform, this impact assessment will support decision makers to apply the most effective control measures. These science-based decision support systems allow all actors in the food and feed chain to express their grip on the mycotoxin contamination thus increasing consumers' confidence in Agro-food products and strengthening the EU competitive position.

\section{Acknowledgements}

The study received funding from the European Union's Horizon 2020 Research and Innovation Program under Grant Agreement Number 678012 as well as from the Ministry of Agriculture, Nature and Food Quality. Furthermore, we would like to thank all MyToolBox partners for their contribution in terms of data collection: from Harper Adams University: D. Henderson-Holding, from the University of Novi Sad: V. Stojšin, T. Dudaš, M. Loc, Z. Savić, T. Barošević, I. Jajić, from Cranfield University: E. Garcia-Cela and A. Medina, from Barilla: Sandro Zanardi, Paolo Lottici, Giulia Barbero, Guido Arlotti, Giovanni Tribuzio, from BIOMIN: Daniela Kotz, Stephan Rose, Timothy Jankins, Veronika Nagl, and from Wageningen University: Cheng Liu.

\section{Conflict of interest}

Authors declare to have to no conflict of interest.

\section{References}

Battilani, P., Toscano, P., Van der Fels-Klerx, H.J., Moretti, A., Camardo Leggieri, M., Brera, C., Rortais, A., Goumperis, T. and Robinson, T., 2016. Aflatoxin $B_{1}$ contamination in maize in Europe increases due to climate change. Scientific Reports 6: 24328.
Budakov, D., Barošević, T., Savić, Z., Stojšin, V., Grahovac, M., Dudaš, T. and Bagi, F., 2019. Relationship between susceptibility to aflatoxin contamination and yield in maize hybrids. Poster presented at WMF meets IUPAC, 14-16/10/2019, Belfast, UK.

Department for Environment Food \& Rural Affairs (DEFRA), 2018. Farming statistics - first estimated of 2018 UK wheat and barley production. Available at: https://tinyurl.com/yxd5jrf9.

European Commission (EC), 2002. Directive 2002/32/EC of the European Parliament and of the Council of 7 May 2002 on undesirable substances in animal feed. Official Journal of the European Union L 140: 10-22.

European Commission (EC), 2006a. Commission Recommendation of 17 August 2006 on the presence of deoxynivalenol, zearalenone, ochratoxin A, T-2 and HT-2 and fumonisins in products intended for animal feeding (2006/576/EC). Official Journal of the European Union L 229: 7-9.

European Commission (EC), 2006b. Commission Regulation (EC) No 1881/2006 of 19 December 2006 setting maximum levels for certain contaminants in foodstuffs. Official Journal of the European Union L 364: 5-24.

European Commission (EC), 2015. Decision C 2453: Horizon 2020 Work Programme 2014 - 2015: Food Security, sustainable agriculture and forestry, marine and maritime and inland water research and bioeconomy (revised). Available at: https://tinyurl. com/hdqanq8.

Edwards, S.G. and Jennings, P., 2018. Impact of agronomic factors on Fusarium mycotoxins in harvested wheat. Food Additives and Contaminants Part A 35: 2443-2454.

Eurostat, 2015. Selling prices of crop products (absolute prices) annual price from 2000 onwards. Available at: https://tinyurl.com/ z2sxbq6.

Eurostat, 2019. Crop production in EU standard humidity. Available at: https://tinyurl.com/v7guz9v.

Garcia-Cela, E., Kiaitsi, E., Sulyok, M., Krska, R., Medina, A., Petit Damico, I. and Magan, N., 2019. Influence of storage environment on maize grain: $\mathrm{CO}_{2}$ production, dry matter losses and aflatoxins contamination. Food Additives and Contaminants Part A 36: 175185. https://doi.org/10.1080/19440049.2018.1556403.

Heyndrickx, E., Sioen, I., Huybrechts, B., Callebaut, A., De Henauw, S. and De Saeger, S., 2015. Human biomonitoring of multiple mycotoxins in the Belgian population: results of the BIOMYCO study. Environment International 84: 82-89. https://doi. org/10.1016/j.envint.2015.06.011.

Kang'ethe, E.K., Gatwiri, M., Sirma, A.J., Ouko, E.O., MburuguMusoti, C.K., Kitala, P.M., Nduhiu, G.J., Nderitu, J.G., Mungatu, J.K., Hietaniemi, V., Joutsjoki, V. and Korhonen, H.J., 2017. Exposure of Kenyan population to aflatoxins in foods with special reference to Nandi and Makueni counties. Food Quality and Safety 1: 131-137. https://doi.org/10.1093/fqsafe/fyx011.

Khatibi, P.A., Berger, G., Wilson, J., Brooks, W.S., McMaster, N., Griffey, C.A., Hicks, K.B., Nghiem, N.P. and Schmale, D.G., 2014. A comparison of two milling strategies to reduce the mycotoxin deoxynivalenol in barley. Journal of Agricultural and Food Chemistry 62: 4204-4213. https://doi.org/10.1021/jf501208x. 
Kotz, D., Rose, S., Schatzmayr, D. and Schatzmayr, G., 2018. Enzymatic detoxification of mycotoxins in the bioethanol process. Available at: https://tinyurl.com/y32qwl4w.

Krska, R., Nijs, M., McNerney, O., Pichler, M., Gilbert, J., Edwards, S., Suman, M., Magan, N., Rossi, V., Van der Fels-Klerx, H.J., Bagi, F., Poschmaier, B., Sulyok, M., Berthiller, F. and Egmond, H., 2016. Safe food and feed through an integrated toolbox for mycotoxin management: the MyToolBox approach. World Mycotoxin Journal 9: 487-495. https://doi.org/10.3920/WMJ2016.2136.

McMullen, M., Bergstrom, G., De Wolf, E., Dill-Macky, R., Hershman, D., Shaner, G. and Van Sanford, D., 2012. A unified effort to fight an enemy of wheat and barley: Fusarium head blight. Plant Disease 96: $1712-1728$.

Miocinovic, J., Keskic, T., Miloradovic, Z., Kos, A., Tomasevic, I. and Pudja, P., 2017. The aflatoxin $M_{1}$ crisis in the Serbian dairy sector: the year after. Food Additives and Contaminants Part B 10: 1-4. https://doi.org/10.1080/19393210.2016.1210243.

Ndenn, J., Diedhiou, P. and Atanda, O., 2015. The economic impact of aflatoxins in West Africa: the case of Gambia, Nigeria and Senegal. PACA secretariat. https://tinyurl.com/y6qr9kt3.

Organisation for Economic Cooperation and Development (OECD), 2017. OECD-FAO Agricultural outlook 2017-2016. OECD Publishing. Available at: https://tinyurl.com/ydg6jpe4.

Rapid Alert System for Food and Feed (RASFF), 2019. The RASFF 2018 annual report. Available at: https://tinyurl.com/y92y6l6j.

Ríos, G., Pinson-Gadais, L., Abecassis, J., Zakhia-Rozis, N. and Lullien-Pellerin, V., 2009. Assessment of dehulling efficiency to reduce deoxynivalenol and Fusarium level in durum wheat grains. Journal of Cereal Science 49: 387-392. https://doi.org/10.1016/j. jcs.2009.01.003.

Savary, S., Ficke, A., Aubertot, J.N. and Hollier, C., 2012. Crop losses due to diseases and their implications for global food production losses and food security. Food Security 4: 519-537.
Savic, Z., Dudas, T., Loc, M., Grahovac, M., Budakov, D., Jajic, I., Krstovic, S., Barosevic, T., Krska, R., Sulyok, M., Stojsin, V., Petres, M., Stankov, A., Vukotic, J. and Bagi, F., 2020. Biological control of aflatoxin in maize grown in Serbia. Toxins 12: 162. https://doi. org/10.3390/toxins12030162.

Scherm, B., Balmas, V., Spanu, F., Pani, G., Delogu, G., Pasquali, M. and Migheli, Q., 2013. Fusarium culmorum: causal agent of foot and root rot and head blight on wheat. Molecular Plant Pathology 14: 323-341.

Streit, E., Schwab, C., Sulyok, M., Naehrer, K., Krska, R. and Schatzmayr, G., 2013. Multi-mycotoxin screening reveals the occurrence of 139 different secondary metabolites in feed and feed ingredients. Toxins 5: 504-523.

Tirado, M.C., Clarke, R., Jaykus, L.A., McQuatters-Gollop, A. and Frank, J.M., 2010. Climate change and food safety: a review. Food Research International 43: 1745-1765. https://doi.org/10.1016/j. foodres.2010.07.003.

Udomkun, P., Wiredu, A.N., Nagle, M., Bandyopadhyay, R., Müller, J. and Vanlauwe, B., 2017. Mycotoxins in Sub-Saharan Africa: present situation, socio-economic impact, awareness, and outlook. Food Control 72: 110-122. https://doi.org/10.1016/j.foodcont.2016.07.039. Van der Fels-Klerx, H.J., Vermeulen, L.C., Gavai, A.K. and Liu, C., 2019. Climate change impacts on aflatoxin $B_{1}$ in maize and aflatoxin $M_{1}$ in milk: a case study of maize grown in Eastern Europe and imported to the Netherlands. PLoS ONE 14: e0218956.

Visconti, A., Haidukowski, E.M., Pascale, M. and Silvestri, M., 2004. Reduction of deoxynivalenol during durum wheat processing and spaghetti cooking. Toxicology Letters 153: 181-189. https://doi. org/10.1016/j.toxlet.2004.04.032.

Zorn, A., Musa, T. and Lips, M., 2017. Costs of preventive agronomic measures to reduce deoxynivalenol in wheat. Journal of Agricultural Science 155: 1033-1044. https://doi.org/10.1017/ S0021859617000247. 